\title{
What's at Stake for Tribes? - The U.S. Department of Justice Office of Legal Counsel Opinion on Internet Gaming, Testimony of Dean Kevin K. Washburn, Oversight Hearing Before the United States Senate Committee on Indian Affairs, 112th Congress, Second Session
}

Kevin Washburn

University of New Mexico - School of Law

Follow this and additional works at: https://digitalrepository.unm.edu/law_facultyscholarship

Part of the Indian and Aboriginal Law Commons

\section{Recommended Citation}

Kevin Washburn, What's at Stake for Tribes? - The U.S. Department of Justice Office of Legal Counsel Opinion on Internet Gaming, Testimony of Dean Kevin K. Washburn, Oversight Hearing Before the United States Senate Committee on Indian Affairs, 112th Congress, Second Session, (2012).

Available at: https://digitalrepository.unm.edu/law_facultyscholarship/521

This Court Filing is brought to you for free and open access by the UNM School of Law at UNM Digital Repository. It has been accepted for inclusion in Faculty Scholarship by an authorized administrator of UNM Digital Repository. For more information, please contact amywinter@unm.edu, Isloane@salud.unm.edu,

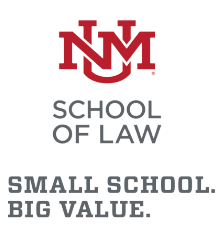

SMALL SCHO
BIG VALUE. 


\title{
What's At Stake For Tribes? - The U.S. DePartment OF JUSTICE OfFice OF Legal COUNSEL OPINION ON INTERNET GAMING
}

\author{
TESTimony OF DEAN KEVIN K. WAShbURN*
}

\author{
OVERSIGHT HEARING BEFORE THE \\ UNITED STATES SENATE COMMITTEE ON INDIAN AFFAIRS \\ (Daniel K. AKaka, Chairman)
}

$112^{\mathrm{TH}}$ CONGRESS, SECOND SESSION

ThURSDAY, FEBRUARY 9, 2012

Indian casinos constitute $40 \%$ of the American gaming market. For a large number of American Indian nations, Indian gaming has been a key resource in facilitating tribal self-governance and self-determination. Approximately 237 tribes operate 442 Indian gaming facilities in the United States. ${ }^{1}$ Given the importance of Indian gaming to tribal governments, Congress must consider how online gaming will affect Indian tribes and insure that any federal laws enacted to regulate Internet gaming give Indian tribes a fair opportunity to share in the Internet gaming boom.

The Supreme Court recognized that tribes had inherent powers to regulate gaming on their own lands in California v. Cabazon Band of Missions Indians ${ }^{2}$ in 1987. That decision produced a nationwide debate on Indian gaming that was largely resolved the next year when President Ronald Reagan signed the Indian Gaming Regulatory Act into law. The Reagan administration was strongly supportive of Indian gaming even before the Cabazon decision. The Reagan Administration believed that revenues from Indian gaming could increase tribal self-sufficiency and reduce tribal dependence on federal appropriations. When it enacted IGRA, Congress recognized the exclusive right of tribes to regulate gaming on their lands and sought to promote tribal economic development, self-sufficiency and strong self government. ${ }^{3}$ Moreover, Congress refused to privatize the benefits of Indian gaming. It mandated in IGRA that gaming revenues

\footnotetext{
* Dean, University of New Mexico School of Law. The author provides his title for identification purposes only. The remarks made herein are made only in his role as an academic providing independent commentary, and are not made in any official capacity. The author thanks his research assistant, Anne Illanes-Meyers for her help in preparing this testimony.

2009 Economic Impact Report, NAT'L INDIAN GAMING ASS'N $\quad$ (NIGA) 6 http://www.indiangaming.org/info/NIGA_2009_Economic_Impact_Report.pdf.

${ }^{2} 480$ U.S. 202 (1987).

${ }^{3}$ Indian Gaming Regulatory Act, 25 U.S.C.§ 2701 et seq. (1988).
} 
must be used primarily for public purposes, naming five authorized uses: "(i) to fund tribal government operations or programs; (ii) to provide for the general welfare of the Indian tribe and its members; (iii) to promote tribal economic development; (iv) to donate to charitable organizations; or (v) to help fund operations of local government agencies."4

The legal regime set forth in IGRA has allowed many tribes to prosper. The Reagan Administration's hopes for Indian gaming have been realized, probably beyond their wildest expectations. Indian gaming has been the greatest economic engine on Indian reservations that the United States has ever seen. From 1998 to 2010, Indian Gaming grossed more than \$246.2 billion nationwide. ${ }^{5}$ Consistent with the purposes specified by Congress, most of these have been used to fund tribal operations and promote the economic development and welfare of tribes and Indian people.

For instance, according to the National Indian Gaming Association's (NIGA) Economic Impact Report for 2009, 237 Indian tribes in 28 states had used Indian gaming to create new jobs, fund essential government services and rebuild communities. In 2009 tribal governments generated $\$ 26.2$ billion gross revenue from gaming alone - $20 \%$ of that net revenue was dedicated to education, children and elders, culture and charity, $19 \%$ to economic development, $17 \%$ to health care, $17 \%$ to police and fire protection, $16 \%$ towards infrastructure and $11 \%$ towards housing. ${ }^{6}$ While tribal revenues allocation plans that provide for per capita payments to individual tribal members have been approved by the Secretary of the Interior and have earned a great deal of press attention, most of these payments have done little more than to increase household income and lift some Indian citizens out of poverty. In addition to gaming revenues, tribes generated $\$ 3.2$ billion in gross revenue from related hospitality and entertainment services such as resorts and entertainment complexes. ${ }^{7}$ As of 2009, tribal governments had directly or indirectly generated 628,000 jobs nationwide for American Indians and others. ${ }^{8}$ As a result of gaming, tribes have experienced extensive economic development and built strong governmental infrastructures.

In sum, gaming has assisted in producing strong tribal governmental infrastructures. Tribal gaming revenues have been a boon to the federal government as well. In light of the federal government's trust responsibility to the tribes, it would likely have had to spend more on federal

\footnotetext{
${ }^{4} 25$ U.S.C. $§ 2710(2)(B)(i)-(v)$.

5 See Gaming Revenue Reports, NAT'L INDIAN GAMING COMm'N (NIGC), http://www.nigc.gov/Gaming_Revenue_Reports.aspx.

${ }^{6}$ Economic Report, supra note 1 at 11.

${ }^{7}$ Id.

${ }^{8} I d$. at 7 .
} 
Indian programs in the absence of Indian gaming. In addition, Indian gaming revenues have produced tax revenues for the federal government, both directly and indirectly, and revenue shares for state governments.

Although predictions are difficult, especially about the future, Internet gaming poses some magnitude of threat to the brick and mortar casino industry, including tribal casinos. Federal policy toward Internet gaming going forward should recognize the significant risk to the stable revenue stream upon which many tribes have been able to depend. Under the worst case scenario, a shift in the market for gaming away from land-based casinos and toward Internet gaming could vastly increase revenues to private and even off-shore Internet gaming companies and decrease tribal governmental revenues, plunging some tribal nations back into poverty. Federal policy must recognize and seek to mitigate this risk, so as to preserve gaming as a viable means of raising governmental resources for tribal governments.

\section{The Demand for Internet Gaming Should be Recognized and Internet Gaming Should be Legalized and Regulated}

The popularity of Internet gaming has been growing, both globally and in the United States. According to H2 Gambling Capital, global online gambling revenue in 2010 was nearly \$30 billion, and less than 15 percent of that came from the U.S. ${ }^{9}$ In light of the strong public demand for Internet gaming, such gambling activity is bound to occur. If it is not regulated, it will present all of the risks inherent to unregulated gaming, such as compulsive gambling, money laundering, unwise extension of credit, and other ills. Indeed, the greatest threat is not legalizing and regulating Internet gaming.

While the recent opinion by the Office of Legal Counsel at the Department of Justice has produced chaos, it has forced a discussion that is due. It is long since time for policy makers in the United States to address Internet gaming. While our model of government with its separation of powers has been generally successful in preventing governmental tyranny, it has produced a very uneven approach toward Internet gaming. Indeed, the approach toward Internet gaming in the United States has vacillated between prohibition and Ostrich-style avoidance. Congressional policy makers, apparently lacking the will to address Internet gaming head on, have sought to place barriers in its path by, for example, prohibiting the use of credit cards. Prosecutors, representing the Executive Branch, have sometimes ignored Internet gaming, and have at other times brought their most significant prohibitory powers to bear, seeking to incarcerate purveyors

9 Online Gambling, AMERICAN GAMING ASSOCIATION (AGA), http://www.americangaming.org/governmentaffairs/key-issues/online-gambling. 
of Internet gaming. If history is any guide, prohibition undermines governmental control and places such control and profits in black market entities. This has produced a haphazard approach. One of the problems in the current federal approach is that it has fallen very unevenly on Internet providers, scaring away legitimate companies and rewarding with great riches some individuals who are willing to take the significant legal risks involved. It is time for the United States to formulate a coherent approach toward Internet gaming.

Through appropriate regulation, approximately 85 countries have been able to provide their citizens with consumer protections while reaping the economic benefits of online gaming. ${ }^{10}$ The potential revenues are significant. Rick Bronson, Chairman of U.S. Digital Gaming, has estimated that online poker could generate $\$ 12$ billion annual revenue in the U.S. ${ }^{11}$ With the prospect of generating more governmental revenue through taxation, the support to legalize online gaming is rapidly mounting. California has estimated that legalizing online poker would net the state $\$ 100$ to $\$ 250$ million a year which could help address its $\$ 9.2$ billion budget shortfall. ${ }^{12}$ The state of Iowa released a study in December 2011 which predicted online poker alone could net the state $\$ 3$ million to $\$ 13$ million annually. ${ }^{13}$

If legalized and regulated, Internet gaming would no longer pose the societal threat that many believe it does. Internet gaming can be regulated. In fact, the AGA has stated, "our concerns about technology have been eliminated by advancements in the field, and [we] believe that the technology now exists to properly regulate Internet gambling [and] provide appropriate consumer protections for individuals..." ${ }^{, 14}$ With increased consumer protection and the possibility of new revenue for governments, online gaming in the United States is inevitable. In fact, Professor I. Nelson Rose has predicted that, in light of the Department of Justice's new interpretation of the Wire Act, states are going to move faster to approve online gaming than they did lotteries. I concur with his prediction. It is imperative that Congressional policy makers address Internet gaming. The United States should enact legislation at the federal level to create an efficient, uniform regulatory system that can protect consumers, address potential social

\footnotetext{
${ }^{10}$ Testimony of Hon. Alfonse D'Amato, U.S. Senate Committee on Indian Affairs, Nov. 17, 2011, available at http://indian.senate.gov/hearings/upload/Alfonse-D-Amato-testimony.pdf.

${ }^{11}$ Enjoli Francis, Online Gaming Casinos to 'Sweep' U.S. in 2012, ABC NEwS, Dec. 28, 2011, available at http://abcnews.go.com/blogs/headlines/2011/12/winning-online-gambling-casinos-to-sweep-u-s-in-2012/.

${ }^{12}$ Michael Cooper, As States Weigh Online Gambling, Profit May be Small, N.Y. TiMES, Jan. 17, 2012, available at http://www.nytimes.com/2012/01/18/us/more-states-look-to-legalize-online-gambling.html.

${ }^{13} I d$.

${ }^{14}$ Online Gaming, supra note 11.
} 
harms of Internet gaming, and provide needed regulatory structure and oversight of this growing industry.

\section{Regulation of Internet Gaming Should be Federalized}

The Internet has fundamentally changed commerce in the United States and throughout the world. Electrons simply do not know political boundaries. As a result, the Internet undermines efforts to preserve the salience of political borders in an increasingly global world. The Department of Justice's most recent interpretation of the Wire Act allows intrastate online gaming, which further dissolves geographic boundaries and complicates regulation. It is inevitable that a gambler in State X may seek to gamble at his favorite casino located in State Y. While it is possible to declare such action illegal, it is much more difficult to stop it. Moreover, it is not clear why it should be stopped. If an action is legal in both states, why shouldn't an American be able to gamble in either location? The only entity that can effectively regulate both situations, however, is the United State government. Presumably, this is the reason that the drafters included the Interstate Commerce Clause in the Constitution, giving the federal government the exclusive authority to regulate commerce between people in different states.

Federal regulation is justified for other reasons as well. Individual states simply are not equipped to regulate online gaming and it would be highly inefficient for companies and taxpayers to have 51 different American regulatory regimes. Moreover, in a field in which the technology is rapidly advancing, the federal government has greater resources and fewer jurisdictional hurdles to regulating this expansive industry. The federal government should take action before 30 to 40 states begin investing valuable public resources to build regulatory regimes.

The AGA is also concerned with state regulation of online gaming and believes that existing laws do not adequately protect the millions of Americans who gamble online every day. In advocating for an encompassing legal framework to regulate Internet gambling, the AGA explained,

"[a]lthough each state should have the discretion to decide whether or not to permit online gambling within its borders... individual states should not be able to create their own online gambling regimes. The result would be a legal patchwork that would make little economic sense, with online poker permitted in one state, a state lottery offering casino games in a second state, and a third state authorizing only Internet blackjack. The result would be confusion for consumers and an inefficient overlap in regulatory effort. 
Thus the only proper way to regulate such an expansive industry is through a federal agency."15

I agree. This potential regulatory calamity has already begun to unfold among states on the East Coast. When New Jersey Governor Chris Christie announced that he wanted New Jersey to be the online gaming capital of the word, Massachusetts quickly announced plans for increased gaming opportunities. Upon hearing rumors of increasing competition, Connecticut Governor Dannel Malloy began talks with the state's two largest tribes to put them in charge of Connecticut's new online gaming enterprise. ${ }^{16}$ The result could be a "race to the bottom" with commerce moving toward the state with the weakest regulatory controls. In sum, we can already see complex problems emerging if we allow individual states to regulate a borderless industry.

For purposes of gaming regulation, the risks associated with gambling are similar throughout the country. The risks include compulsive gambling, organized crime, embezzlement, tax evasion and money laundering. Given the uniformity of the risks, it makes little sense to have a New Jersey approach to Internet gaming regulation and a Massachusetts approach. With its broad reach, significant resources, and existing infrastructure to monitor and address financial risks, the federal government should occupy the field. Indeed, without a systematic, federal regulatory scheme, laws will vary nationwide likely spurring discrimination or market domination issues and increase the number of diversity suits filed in federal court.

\section{To Preserve Socioeconomic Gains that Have Occurred During the Past Quarter Century, Tribes Must Have an Equal Opportunity to Engage in Internet Gaming}

The story of Indian Nations is a story of survival. Without equal opportunity to participate in the next frontier in gaming, tribes are at risk of falling back into pre-Indian gaming socioeconomic conditions.

Prior to the introduction of gaming, American Indian communities had been correctly likened to Third World countries operating within state borders. ${ }^{17}$ Nationally, American Indian families

\footnotetext{
15 David O. Stewart, Online Gaming Five Years After UIGEA, AGA, 18 (2011). http://www.americangaming.org/files/aga/uploads/docs/final_online_gambling_white_paper_5-18-11.pdf.

${ }^{16}$ Lucy Nalpathanchil, Conn. Tribes Hope to Win Big With Online Poker, NPR, Jan. 24, 2012, available at http://www.npr.org/2012/01/24/145654870/in-conn-tribes-hope-to-win-big-with-online-poker.

${ }^{17}$ James I. Schaap, The Growth of the Native American Gaming Industry What Has the Past Provided, and What Does the Future Hold?, 34 AMERICAN INDIAN Q. 365, 368 (Summer 2010).
} 
lived below the poverty line at a rate nearly three times the national average. ${ }^{18}$ For example, in New Mexico nearly half of the Indians lived below the poverty level and one-quarter lived in homes without plumbing. ${ }^{19}$ Approximately 90,000 American Indian families in Indian country were homeless or "under housed." 20 Before Indian gaming, American Indians suffered from diabetes at two and a half times the national rate and suicide rates were between two and three times the national average. ${ }^{21}$

Indian gaming has not solved these problems, but it has improved them. Indian gaming has not only had a positive economic and social impact on the tribes themselves, but also on the surrounding communities. ${ }^{22}$ Unemployment rates and poverty percentages have dramatically decreased, as have instances of suicide, domestic violence and crime, while graduation rates of tribal members have increased. ${ }^{23}$

Despite the success of Indian gaming in improving life on the Reservation, much remains to be done. As of 2010, the poverty rate among American Indians was 25.3 percent compared to the national average of 12.6 percent. $^{24}$ Only 13.6 percent of American Indians have attained a bachelor's degree or higher compared with 27.2 percent of the general public. ${ }^{25}$ About 2.6 percent of homes in tribal areas lack complete plumbing facilities compared with .42 percent nationwide. $^{26}$ It is imperative that Indians be given equal opportunity to compete on the same level as commercial casinos in order to continue combating these and other socioeconomic problems endemic to their tribes.

\footnotetext{
${ }^{18}$ American Indian Gaming Policy and Its Socio-Economic Effects - A Report to the National Gaming Impact Study Commission, NIGA,, July 1998 available at http:ww...indiangaming.org/library/resource-center/index.html.

${ }_{19}$ Jonathon Taylor \& Joseph Kalt, American Indians on Reservations: A Databook of Socioeconomic Change between the 1990 and 2000 Censuses, Harvard Project on American Indian Economic Development, Harvard University, Cambridge, MA, January 2005.

${ }^{20}$ American Indian Gaming Policy, supra note 18.

${ }^{21} I d$.

${ }^{22}$ The Growth of the Native American Gaming Industry, supra note 17 at 374 (citing Jonathan Taylor, Matthew Krepps \& Patricia Wang, The National Evidence on the Socioeconomic Impacts of American Indian Gaming, April 2000, Harvard University/Lexecon, http://www.indiangaming.org/library/articles/the-economic-developmentjourney.html, explaining that "this effect is driven by the fact that Indian casinos are more likely to be located in relatively economically depressed areas displaying lower average incomes prior to casino introductions.”)

${ }^{23} I d$. at 375.

${ }^{24}$ The Growth of the Native American Gaming Industry, supra note 17 at 377.

${ }^{25} I d$.

${ }^{26} I d$.
} 
Some members of the gaming industry agree that tribes have an important role to play in our Internet gaming future. In November of 2011, the Honorable Alfonse D'Amato, Chairman of the Poker Players Alliance, testified before this committee that, "Indian Country should be substantial players in a regulated U.S. market. We would like to see Tribal governments as federally-recognized licensing bodies...as licensed operators, as well as affiliates and network partners for other licensed operators." 27 To further progress in difficult socio-economic conditions on Indian reservations, and to prevent backsliding toward poverty for those tribes who have escaped it, it is imperative that tribes are given equal access to online gaming. Implementing a federal approach toward Internet gaming can facilitate this goal.

\section{Conclusion}

Online gaming is the next frontier in gambling for both commercial and tribal casinos. While the United States should recognize the demand for online gaming and create legal avenues for this demand to be satisfied, the federal government and tribal nations must preserve the great progress made in Indian communities. Just as the Internet revolutionized the sale of retail goods, it will change gambling dramatically. While online sales have had a profound impact on retail stores, existing brick and mortar retailers, just as shopping malls and small retailers, will continue to thrive. Internet gaming will not end the market for brick and mortar casinos, but it will have an impact. Tribes must have an opportunity to participate in online gaming to preserve strong governmental revenue streams that are crucial to the success of Indian people.

Thank you for requesting my views.

Dean Kevin Washburn is the author of a law school casebook, GAMING AND GAMBLING LAW: CASES AND MATERIALS (WolterKluwer/Aspen 2011), and executive editor and principal author of the Indian Gaming chapter of the forthcoming 2012 edition of FELIX S. CoHEN's HANDbOOK OF FEDERAL INDIAN LAW (LexisNexis). Additional scholarship and testimony by Dean Kevin Washburn on Gaming and Indian gaming can be viewed on the web at http://ssrn.com/author=334714.

${ }^{27}$ Testimony of Hon. Alfonse D'Amato, supra note 10. 